\title{
Mechanisims of asthma and allergic disease - 1075. Probiotics in infants for prevention of allergic disease and food hypersensitivity
}

John Sinn

From 2nd WAO International Scientific Conference (WISC 2012)

Hyderabad, India. 6-9 December 2012

\section{Background}

Probiotic ('healthy' bacteria) added to infant feeds have the potential to prevent sensitisation of infants to dietary allergens.

\section{Methods}

Standard methods of the Cochrane Neonatal Review Group were used. Searches were updated October 2011. Randomised and quasi-randomised controlled trials that compared a probiotic to control; or probiotic with added prebiotic (synbiotic) to control were eligible.

\section{Results}

Sixteen studies were eligible. Several ongoing studies and completed studies with no reported allergy results were identified. Eight studies reported adequate randomisation and allocation procedures and used a placebo. Only one study reported $<10 \%$ losses after allocation. Overall, meta-analysis of 12 studies found a significant reduction in infant eczema (1876 infants; RR 0.77; 95\% CI $0.67,0.89$; RD -0.07; -0.12, -0.03 ; NNT 14; 8, 33] from use of probiotic. Moderate $\left(\mathrm{I}^{2}=32 \%\right)$ heterogeneity between studies was found. In subgroup analysis, a significant reduction in eczema was found in infants selected for risk of allergy and unselected infants; infants predominately breast fed; infants treated with L. Rhamnosus (3 studies, 542 infants, RR 0.61; 0.45, 0.82); infants treated with a combination probiotic B. bifidum, B. lactis and L. acidophilus (1 study, 68 infants; RR 0.58; 0.34, 0.97 ); and infants given a synbiotic ( 1 study, 925 infants; RR $0.81 ; 0.66,0.99)$. There was no significant difference

Obstetrics, Gynaecology and Neonatology, University of Sydney, Sydney, Australia in all allergy, asthma, atopic eczema, allergic rhinitis, or food hypersensitivity.

\section{Conclusions}

Further evidence is required before a probiotic or synbiotic can be recommended for prevention of allergy. A well powered, independent trial is required to answer this question.

Published: 23 April 2013

doi:10.1186/1939-4551-6-S1-P72

Cite this article as: Sinn: Mechanisims of asthma and allergic disease 1075. Probiotics in infants for prevention of allergic disease and food hypersensitivity. World Allergy Organization Journal 2013 6(Suppl 1):P72.

Submit your next manuscript to BioMed Central and take full advantage of:

- Convenient online submission

- Thorough peer review

- No space constraints or color figure charges

- Immediate publication on acceptance

- Inclusion in PubMed, CAS, Scopus and Google Scholar

- Research which is freely available for redistribution 